\title{
EVALUATION OF HERBAGE YIELD AND NUTRITIVE VALUE OF EIGHT FORAGE CROP SPECIES
}

\author{
AKDENIZ, H. ${ }^{1}$ - HoSAFLIOĞLU, I. ${ }^{2}$ - KoÇ, A. ${ }^{3}$ - HosSAIN, A. ${ }^{4}$ - ISLAM, M.S. ${ }^{5}$ - IQBAL, M. A. ${ }^{6}-$ \\ IMTIAZ, H..$^{7}$-GHARIB, H. $^{8}-$ El SABAGH, A. ${ }^{{ }^{*}}$ \\ ${ }^{1}$ Department of Field Crops, Faculty of Agriculture, I $\breve{g} d ı r$ University, 7600 Iğdır, Turkey \\ ${ }^{2}$ Department of Landscape Architecture, Faculty of Agriculture, I Ĭdır University, \\ 76000 I $\breve{g} d \imath$, Turkey \\ ${ }^{3}$ General Directorate of Agricultural Affairs, Ankara, Turkey \\ ${ }^{4}$ Bangladesh Wheat and Maize Research Institute, 5200 Dinajpur, Bangladesh \\ ${ }^{5}$ Department of Agronomy, Hajee Mohammad Danesh Science and Technology University, \\ Basherhat, Bangladesh \\ ${ }^{6}$ Department of Agronomy, University of The Poonch, Rawalakot (AJK), Pakistan \\ ${ }^{7}$ Department of Food Science and Technology, University of The Poonch, Rawalakot (AJK), \\ Pakistan \\ ${ }^{8}$ Department of Agronomy, Faculty of Agriculture, Kafrelsheikh University, \\ 33516 Kafr El Sheikh, Egypt \\ *Corresponding author \\ e-mail:ayman.elsabagh@agr.kfs.edu.eg \\ (Received 20 ${ }^{\text {th }}$ Dec 2018; accepted $19^{\text {th }}$ Feb 2019)
}

\begin{abstract}
Determining nutritional quality of indigenous forage species constitutes prerequisite to improve the productivity of ruminants. This research was carried out at the research field of the Agricultural Research and Application Center of Igdir University, Turkey in consecutive two years (2015 \& 2016) to evaluate the herbage yield and nutritive value of eight forage species having diverse genetic make-up. Eight forage species such as Kentucky bluegrass (Poa pratensis var. Geromino), Perennial rye-grass (Lolium perenne var. Ovation), Red rescue (Festuca rubra rubra var. Corail), Slender creeping red fescue (Festuca rubra tricphylla var. Pinafore), Sheep fescue (Festuca ovina var. Ridu), Tall fescue (Festuca arundinaceae var. Jaguar 4G), Chewings fescue (Festuca comutata var. Longfellow II) and Colonial bentgras (Agrostis tenuis var. Aristata) were used as plant materials and the experiment was arranged in a randomized complete design with three replications. Data on biomass yield, crude ash, crude protein, crude oil, crude cellulose, net digestible fiber (NDF), acid detergent fiber (ADF), dry matter intake (DMI), digestible dry matter (DDM) and relative feed value (RFV) were recorded during the investigation. Results of the present study indicated that species 'Tall fescue' (Festuca arundinaceae var. Jaguar 4G) yielded the highest herbage yield, followed by cultivar 'Perennial rye-grass' (Lolium perenne var. Ovation). While, 'Kentucky bluegrass' (Poa pratensis var. Geromino) was found to be inferior to all other forage species in the studied years. When nutritional quality was observed, the species 'Colonial bentgrass' (Agrostis tenuis var. Aristata) had the maximum crude protein and RFV, while cultivar 'Perennial rye-grass' had significantly higher RFV, DMI, DMD and the minimum fiber content, which indicated its superior quality for milch animals.
\end{abstract}

Keywords: forage species, Ĭgdır-Turkey environmental, nutritional quality, yield.

Abbreviations: ADF: acid detergent fiber; DDM: digestible dry matter; DMI: dry matter intake; NDF: net digestible fiber; RFV: relative feed value 


\section{Introduction}

To meet the food demand of increasing population, crop intensification and a sustainability should be continued globally (Jiang and Huang, 2001, Iqbal et al., 2019). The efficient use of farm resources, such as organic manure and home-grown forage, is the key to a sustainable and successful farm operation for the grassland farmers, while to improve the quality of home-grown forage from meadows and pastures, different strategies have been developed (Iqbal et al., 2018). For example, establishment and renovation of grassland by over seeding with high-quality seed mixtures are the most importance task to meet the fodder demand (Poetsch et al., 2016).

Turkey is bestowed with a great number of animals; however, animals' productivity in terms of milk and meat production is very low as compared to their potential. One of the main reasons for this under-performance of animals is owing to deficiency of good quality forages. The most important feed sources are pastures for grazing and those are composed of forage crops such as alfalfa, vetch and sainfoin grown as field crops (Iqbal et al., 2017). Cultivation of forage crops as field crops is rather low in Turkey and areas under forage crop are continuously declining due to increasing demand for food crops. Therefore, it is necessary to expand the forage crops growing area, along with investigating intercropping and crop rotation, as well as developing improved high yielding forage crop species. Although there are some species of vetch and alfalfa, but most of these forage species are perennial grasses; as a result, the number of improved varieties is far beyond the demand (Özpınar et al., 2014).

Among the forage species, 'Kentucky bluegrass' is a common turf species used on golf courses, sports fields, municipal parks, sod farms, road banks, as well as residential and school yards. 'Turfgrass' productivity is largely influenced by fertilization, particularly nitrogen. However, a greater $\mathrm{N}$ use efficiency is observed in the soils with low N levels (Below, 1995; Muir et al., 2001; Wims et al., 2013). 'Turfgrass' plants need sufficient soil moisture to maintain normal growth and development. The ornamental value and quality of 'Turfgrass' is severely affected by drought (Kanapeckas et al., 2008). However, the most cool-season 'Turfgrass' species are particularly susceptible to salinity stress during seed germination, with the possible exception of 'perennial ryegrass' (Lolium perenne L.). 'Ryegrass' is one of the most important and valuable forage plants in grasslands and constitutes an indispensable component of seed mixtures for meadows, pastures, ley farming, and re-seeding measures (Poetsch et al., 2016). Grazed perennial ryegrass is one of the most important forages for dairy cows in temperate regions due to its high forage yield and nutritive value (van Wijk et al., 1993; Lemus et al., 2008; Kering et al., 2012; Kumar et al., 2016), and hence, provides a cheaper feed than silage or concentrates. Traditionally, perennial ryegrass species were mainly bred for high forage production. Many studies indicated that environmental stresses affected physiological changes, especially antioxidant responses, in many cool-season 'Turfgrass' species (Xu et al., 2006; Senthil-Kumar et al., 2007). The ability for avoiding oxidative stress is a very important factor in determining the environmental stress tolerance of turf-grasses (Wang et al., 2012). Creeping bent-grass (Agrostis stolonifera L.) establishment and management practices are well understood for this turf-grass, hence its popularity is widespread (Beard, 2002).

'Red fescue' (Festuca rubra), 'Sheep fescue' ( $F$. ovina), and 'meadow fescue' ( $F$. pratensis) are the subjects of intensive research. All are valued for both forage production and special purposes, ranging from the preparation of sport grounds, parks, 
and house gardens, to preventing the erosion of soil from embankments and railroads (Stanisavljević et al., 2012). 'Tall fescue' has been considered one of the best-adapted cool-season grasses for hot and dry conditions (Turgeon, 1980; Smit et al., 2005a, b).

It is well-established that forage grasses require less intensive management and inputs that impart them superiority over conventional turf blends by reducing the need for fertilization, pest control, irrigation and mowing. The quality of a low maintenance turf is usually not so high, since minimal inputs cannot be expected to produce high quality forage (Prendes and Palencia, 2015). Up-till now, there are a very few studies which provide concrete and conclusive results pertaining to the variability of yield and seed quality including viability of these forage species. It is hypothesized that some of the forage species may outperform others in terms of herbage yield and nutritional quality under Mediterranean environment. Thus, considering the burning issue, the aim of this study was to assess the herbage yield and nutritive value for some forage crop species grown in Mediterranean conditions to meet the quality feed demand for increasing number of cattle.

\section{Materials and methods}

\section{Locations and soil properties}

This research was carried out at the research field of the Agricultural Research and Application Center, Igdir University, Turkey during consecutive two years (2015 \& 2016). Soil of the research site was characterized as clay-loamy texture, highly alkaline (pH: 8.6), lightly salted (EC: $1.37 \mathrm{dS} / \mathrm{m}$ ), low organic matter content (1.20\%) and rich in lime $\left(\mathrm{CaCO}_{3}: 22.27 \%\right)$. Beside these, available phosphorus $(\mathrm{P})$ and potassium $(\mathrm{K})$ contents in the soil were found to be $51.7 \mathrm{ppm}$ and $852.4 \mathrm{ppm}$ (Erdogan, 2013).

\section{Treatments and experimental design and using materials}

Selected eight forage species such as Kentucky bluegrass (Poa pratensis var. Geromino), Perennial rye-grass (Lolium perenne var. Ovation), Red rescue (Festuca rubra rubra var. Corail), Slender creeping red fescue (Festuca rubra tricphylla var. Pinafore), Sheep fescue (Festuca ovina var. Ridu), Tall fescue (Festuca arundinaceae var. Jaguar 4G), Chewings fescue (Festuca comutata var. Longfellow II) and Colonial bentgras (Agrostis tenuis var. Aristata) were arranged in a randomized complete design with three replications. Each experimental plot had the net area of $12 \mathrm{~m}^{2}(3 \times 4 \mathrm{~m})$. The list of the forage crops under investigation are described in Table 1.

Table 1. Forage crops used in the experiment

\begin{tabular}{c|c|c}
\hline SL No. & English name & Latin name \\
\hline 1. & Kentucky bluegrass & Poa pratensis var. Geromino \\
2. & Perennial rye-grass & Lolium perenne var. Ovation \\
3. & Red rescue & Festuca rubra rubra var. Corail \\
4. & Slender creeping red fescue & Festuca rubra tricphylla var. Pinafore \\
5. & Sheep fescue & Festuca ovina var. Ridu \\
6. & Tall fescue & Festuca arundinaceae var. Jaguar $4 \mathrm{G}$ \\
7. & Chewings fescue & Festuca comutata var. Longfellow II \\
8. & Colonial bentgras & Agrostis tenuis var. Aristata \\
\hline
\end{tabular}




\section{Experimental procedure}

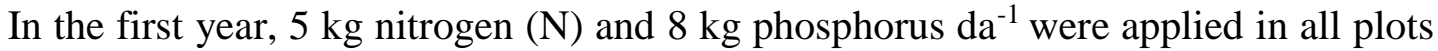
during the final land preparation. In the second year, $15 \mathrm{~kg} \mathrm{da}^{-1}$ nitrogen was applied to all plots. while half of the nitrogen was applied during April and May each year. During first year, seeds of all forage species were sown on 15 March 2014 and no yield could be recorded in this year. Therefore, the data obtained in the first year of the establishing were not taken into consideration and only the second and third year data were evaluated. Irrigation was applied as per field capacity. Cutting time was June 15, 2015 in the second year and June 20, 2016 the third year. After leaving $0.5 \mathrm{~m}$ from the sides of each plots 1 , the rest of the plots $\left(6 \mathrm{~m}^{2}\right)$ were cut with a machine called 'Figaro' and were weighed immediately using spring balance. Since the first year is the establishing year, the second and third year data are taken into consideration and subsequently analyzed statistically.

\section{Chemical analyses}

Chemical analyses regarding crude protein (CP) and ash concentration were performed as per procedures outlined by AOAC (2000). Neutral detergent fiber (NDF), acid detergent fiber (ADF), cellulose and lignin were determined by following Van Soest et al. (1991) using Fiber Tech analyzer (FibraPlus FES 6, Pelican, Chennai, India). Heat-labile $\alpha$-amylase and sodium sulphite were used in NDF solution. Lignin (sa) was determined by dissolving cellulose with sulfuric acid in the ADF residue (Van Soest et al., 1991). Cellulose was estimated as the difference between ADF and lignin (sa) in the sequential analysis and hemicellulose was calculated as difference between NDF and ADF concentrations. Dry matter intake (DMI), digestible of dry matter (DDM), relative feed value (RFV) for different animal functions was determined as described by Undersander et al. (1993).

\section{Statistical analysis}

The obtained data were statistically analyzed, separately and combined, using "SAS" statistical package program. Variable means were compared at the significance level of $\mathrm{P}<0.05$. Correlation coefficients between different yield attributes were done by using the same statistical software (Snedecor and Cochran, 1994).

\section{Results and discussion}

\section{Dry hay yield of different forage species}

It was revealed that 'tall fescue' performed the best over other forage species under study in terms of dry matter yield, this result is in agreement with the finding of Campbell and Xia (2002). Forage cultivars 'Perennial rye-grass' and 'slender creeping red fescue' followed 'tall fescue' in terms of herbage yield in both years. 'Kentucky bluegrass' and 'colonial bentgras' yielded the minimum hay (Fig. 1; Table 2). The significantly higher herbage yield contributed by 'tall fescue' might be attributed to significantly higher plant height and fast regrowth rate after cutting. In addition to this, early and strong spring growth could have positive effect on it (Özpınar et al., 2014, Campbell and Xia, 2002). To achieve appropriate yield and quality herbage and change 
greatly depending on cultural practice, the species, variety and environment (Barutcular et al., 2017; Akdeniz et al., 2018a).

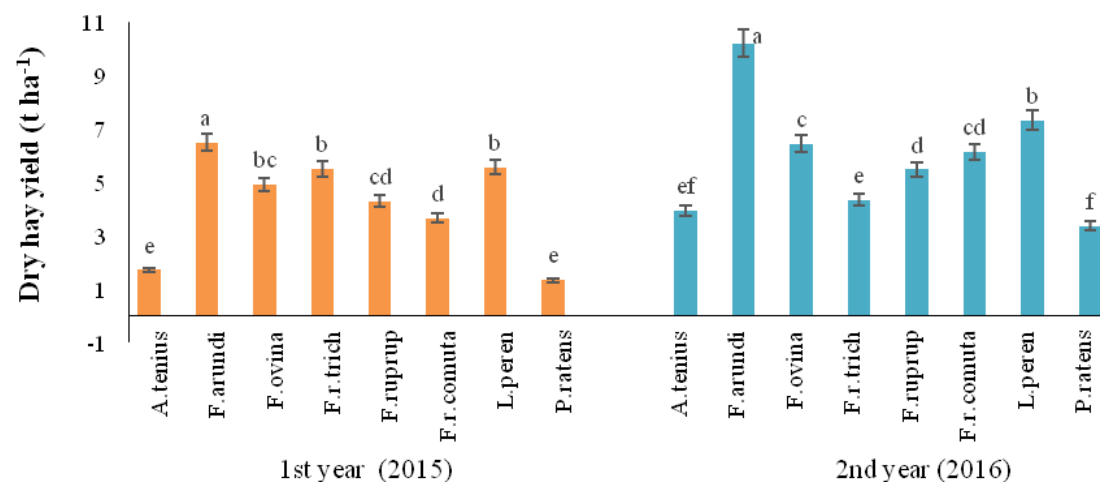

Figure 1. Dry hay yield $\left(t \mathrm{ha}^{-1}\right)$ of different forage species grown under the Mediterranean environment of Turkey during 2015 and 2016. Bar with same letter indicates that does not differ significantly, while with dissimilar letters indicates that differ significantly. Mean $( \pm S E)$ was calculated from three replicates for each forage cultivars. Error bars represent significant difference at $p \leq 0.01$ (LSD test)

Table 2. Dry biomass yield and nutritional quality of hay of different forage species grown under Mediterranean environment during 2015 and 2016

\begin{tabular}{|c|c|c|c|c|c|c|c|c|c|c|}
\hline $\begin{array}{l}\text { Forage } \\
\text { species }\end{array}$ & $\begin{array}{c}\text { Dry hay } \\
\text { yield }\left(\mathrm{t} \mathrm{ha}^{-1}\right)\end{array}$ & $\begin{array}{c}\text { Crude } \\
\text { ash }(\%)\end{array}$ & $\begin{array}{c}\text { Crude } \\
\text { protein }(\%)\end{array}$ & $\begin{array}{c}\text { Crude oil } \\
(\%)\end{array}$ & $\begin{array}{c}\text { Crude } \\
\text { cellulose }(\%)\end{array}$ & NDF $(\%)$ & ADF (\%) & DMI & DDM & RFV \\
\hline & \multicolumn{10}{|c|}{ First year } \\
\hline A. tenius & $1.71 \mathrm{e}$ & $17.12 b$ & $21.06 \mathrm{a}$ & 1.67abc & $39.94 \mathrm{bc}$ & $52.45 \mathrm{bc}$ & 35.33de & $2.29 \mathrm{ab}$ & 61.38 & $109.06 \mathrm{ab}$ \\
\hline F. arundi & $6.50 \mathrm{a}$ & $22.17 \mathrm{a}$ & $15.84 \mathrm{c}$ & $1.07 \mathrm{~cd}$ & $61.25 \mathrm{a}$ & $62.89 \mathrm{a}$ & $39.10 \mathrm{~cd}$ & $1.91 \mathrm{c}$ & 58.44 & $86.45 \mathrm{~cd}$ \\
\hline F. ovina & $4.93 \mathrm{bc}$ & $10.43 \mathrm{~cd}$ & $13.59 \mathrm{de}$ & $1.56 \mathrm{bc}$ & $36.59 \mathrm{~cd}$ & $61.33 \mathrm{a}$ & $43.19 \mathrm{ab}$ & $1.96 \mathrm{c}$ & 55.23 & $84.28 \mathrm{~d}$ \\
\hline F.r. trich & $50 \mathrm{~b}$ & $17.99 \mathrm{~b}$ & $14.143 \mathrm{cde}$ & $0.74 \mathrm{~d}$ & $65.81 \mathrm{a}$ & $64.00 \mathrm{a}$ & $45.78 \mathrm{a}$ & $1.88 \mathrm{c}$ & 50.64 & $73.67 \mathrm{~d}$ \\
\hline F. ruprup & $4.30 \mathrm{~cd}$ & $18.06 \mathrm{~b}$ & $15.60 \mathrm{c}$ & $0.75 \mathrm{~d}$ & $38.26 \mathrm{bcd}$ & $63.71 \mathrm{a}$ & $39.76 b c$ & $1.89 \mathrm{c}$ & 57.93 & $84.72 \mathrm{~d}$ \\
\hline F. r. comuta & $66 \mathrm{~d}$ & $11.09 \mathrm{c}$ & $13.30 \mathrm{e}$ & $0.74 \mathrm{~d}$ & $42.48 \mathrm{~b}$ & $64.28 \mathrm{a}$ & $40.62 \mathrm{bc}$ & $1.87 \mathrm{c}$ & 57.26 & $82.99 \mathrm{~d}$ \\
\hline L. peren & $5.57 \mathrm{~b}$ & $19.00 \mathrm{~b}$ & $17.92 \mathrm{~b}$ & $2.29 \mathrm{a}$ & $33.59 \mathrm{~d}$ & $49.33 c$ & $32.88 \mathrm{e}$ & $2.43 a$ & 63.28 & $119.41 \mathrm{a}$ \\
\hline P. ratens & $33 \mathrm{e}$ & $8.39 \mathrm{~d}$ & $15.25 \mathrm{~cd}$ & $1.91 \mathrm{ab}$ & $42.70 \mathrm{~b}$ & & $37.27 \mathrm{~cd}$ & $2.15 b$ & 59.87 & $99.94 \mathrm{bc}$ \\
\hline \multirow[t]{2}{*}{$\operatorname{LSD}_{(0.05)}$} & 65 & 2.44 & 1.77 & 0.70 & 5.36 & 4.29 & 4.07 & 0.15 & ns & 14.32 \\
\hline & \multicolumn{10}{|c|}{ Second year } \\
\hline A. tenius & & & & & $36.77 \mathrm{e}$ & & & $4.82 \mathrm{a}$ & $56.83 b$ & $212.09 \mathrm{~b}$ \\
\hline F. arundi & $10.23 a$ & $9.54 \mathrm{a}$ & $9.86 \mathrm{bc}$ & 1.15 & $44.85 \mathrm{a}$ & $64.05 \mathrm{c}$ & $47.64 \mathrm{a}$ & $1.87 \mathrm{bc}$ & $51.79 \mathrm{~d}$ & $75.22 \mathrm{~cd}$ \\
\hline F. ovina & $6.46 c$ & $5.57 \mathrm{~d}$ & $5.80 \mathrm{e}$ & 1.41 & 44.06ab & $68.33 b$ & $45.58 \mathrm{ab}$ & $1.76 \mathrm{~cd}$ & $53.39 \mathrm{~cd}$ & $72.71 \mathrm{~d}$ \\
\hline F.r.trich & $4.337 \mathrm{e}$ & $8.49 \mathrm{~b}$ & $8.85 \mathrm{bcd}$ & 1.44 & $43.612 \mathrm{abc}$ & $69.25 b$ & $44.26 \mathrm{~b}$ & $1.73 \mathrm{~cd}$ & $54.42 \mathrm{c}$ & $73.11 \mathrm{~d}$ \\
\hline F. ruprup & $5.48 \mathrm{~d}$ & $6.98 \mathrm{c}$ & $7.91 \mathrm{~d}$ & 0.96 & $41.47 \mathrm{~cd}$ & $70.29 b$ & $46.31 \mathrm{ab}$ & $1.71 \mathrm{~d}$ & $52.83 \mathrm{~cd}$ & $69.91 \mathrm{~d}$ \\
\hline F. r. comuta & $6.13 \mathrm{~cd}$ & $5.44 \mathrm{~d}$ & $8.52 \mathrm{~cd}$ & 1.02 & $41.61 \mathrm{bcd}$ & $83.25 \mathrm{a}$ & $45.21 \mathrm{ab}$ & $1.44 \mathrm{e}$ & $53.68 \mathrm{~cd}$ & $59.99 \mathrm{e}$ \\
\hline L. peren & $7.33 b$ & $9.13 \mathrm{ab}$ & $12.75 \mathrm{a}$ & 1.52 & $36.33 \mathrm{e}$ & $35.51 \mathrm{e}$ & $24.82 \mathrm{c}$ & $4.84 \mathrm{a}$ & $61.24 \mathrm{a}$ & $229.76 a$ \\
\hline P. ratens & $3.36 \mathrm{f}$ & $8.73 \mathrm{ab}$ & $9.74 b c$ & 1.53 & $40.77 \mathrm{~d}$ & $62.63 \mathrm{c}$ & $43.97 \mathrm{~b}$ & $1.92 \mathrm{~b}$ & $54.65 \mathrm{c}$ & $81.19 \mathrm{c}$ \\
\hline $\operatorname{LSD}_{(0.05)}$ & 0.72 & 0.81 & 1.63 & $\mathrm{~ns}$ & 2.49 & 2.20 & 2.49 & 0.15 & 1.99 & 7.38 \\
\hline
\end{tabular}

NDF: neutral detergent fiber; ADF: acid detergent fiber; DMI: intake, digestibility to calculate DM intake; DDM: digestible dry matter; RFV: relative feed value

\section{Crude protein, crude ash, oil content, NDF, ADF and cellulose}

Ash, oil content, NDF, ADF and cellulose were found to be varying among the species under investigation (Figs. 2 and 3; Table 2). However, 'Colonial bentgras' 
proved to be superior to all in terms of crude protein content and it was followed by 'perennial rye-grass'. The minimum crude protein content was recorded by 'sheep fescue' followed by 'chewings fescue'. On the other hand, 'tall fescue' had the maximum ash and was closely followed by 'perennial rye-grass', 'slender creeping red fescue', 'red rescue. Chewings fescue' recorded the lowest crude oil content while 'perennial rye-grass' had quite high oil concentration. 'Perennial rye-grass' remained outstanding by recording the lowest cellulose and NDF as well as ADF contents (Fig. 3; Table 2).

Cereal stover and straws are usually low in crude protein and rich in fiber concentrations, and thus unable to meet the minimum crude protein requirements $(7 \%)$ for maintenance of animals and rumen microbes (Minson, 1990). There is a dire need to supplement this stover with protein rich leguminous forage or non-protein nitrogen or protein sources in order to obtain sustainable supplies of milk from dairy animals. It was observed significant differences among the crops and their interaction with environment regarding yield and quality properties However, variations have been also observed in different agronomic and quality were also noted by Barutcular et al. (2016a, b, c; Akdeniz et al., 2018b; Y1ldırım et al.,2018). The variability in NDF, ADF, cellulose and lignin concentrations of sorghum stover in different species has been reported earlier (Hamed et al., 2015) and it is reported that forage with high NDF levels had higher concentrations of the CB2 fraction, which is more slowly degraded in the rumen, impacting microbial synthesis and animal performance (Ribeiro et al., 2001). Carvalho et al. (2007) reported that NDF concentration influences carbohydrate fraction CB2 and forages high in NDF concentration usually have higher values of CB2.

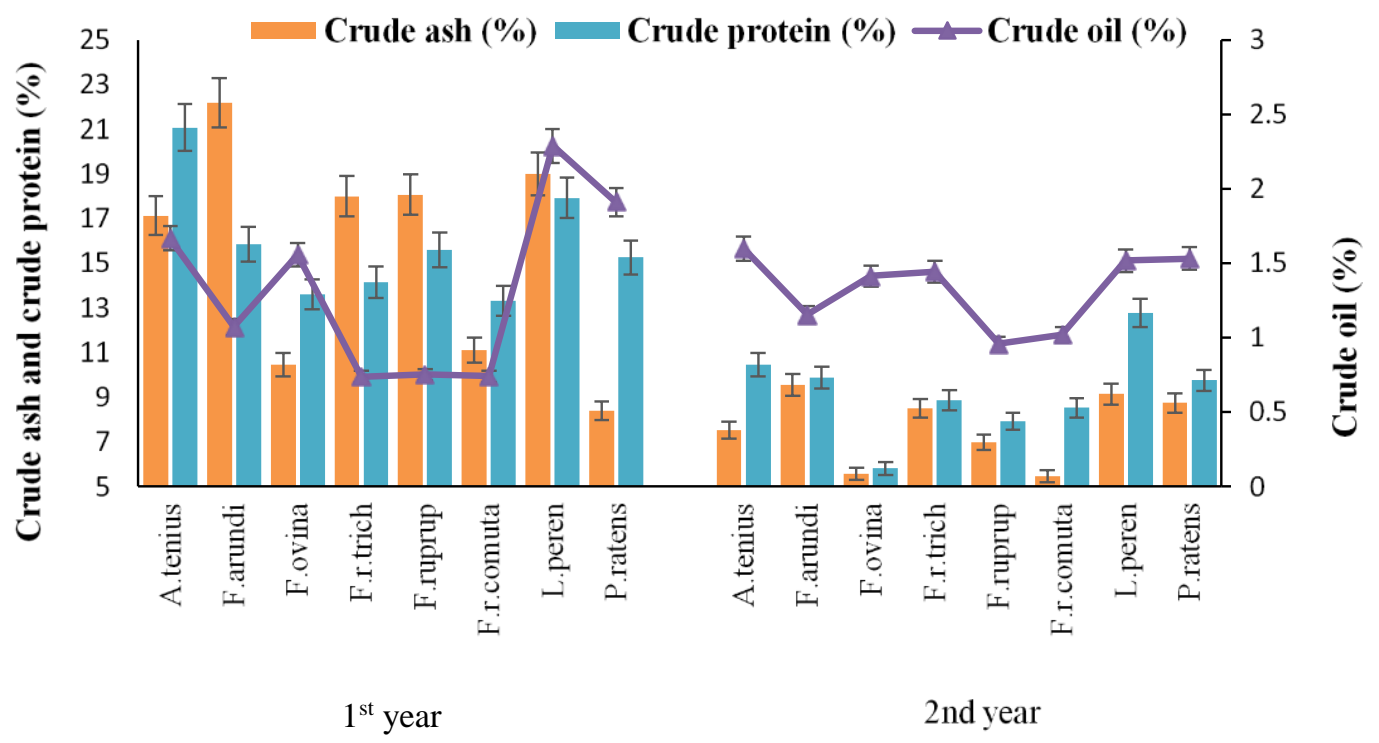

Figure 2. Crude ash, crude protein and crude oil of hay/forage as influenced by different forage species grown under Mediterranean environment

\section{Intake, digestibility and relative feed value}

The calculated values of DMI, DDM and RFV for different forage crops varied significantly during both years of study (Fig. 4). 'Perennial rye-grass' proved its superiority to other forage species by recording the highest DMI, DMD and RFV, while 
it was followed by 'colonial bentgras'. It was also revealed that 'kentucky bluegrass' was better than 'slender creeping red fescue', 'red rescue' and 'chewings fescue', but remained inferior to 'perennial rye-grass' and 'Colonial bentgras'. Dietary fiber concentration, its digestibility and rate of degradation in the rumen are the most important forage characteristics that determine DMI (Roche et al., 2008). We attributed the lower RFV of stover in the present study to its lower quality relative to the whole plants examined at the younger age which is agreement with Bean et al. (2011), who noted that higher NDF and ADF concentrations influence the intake and digestibility of a fodder.

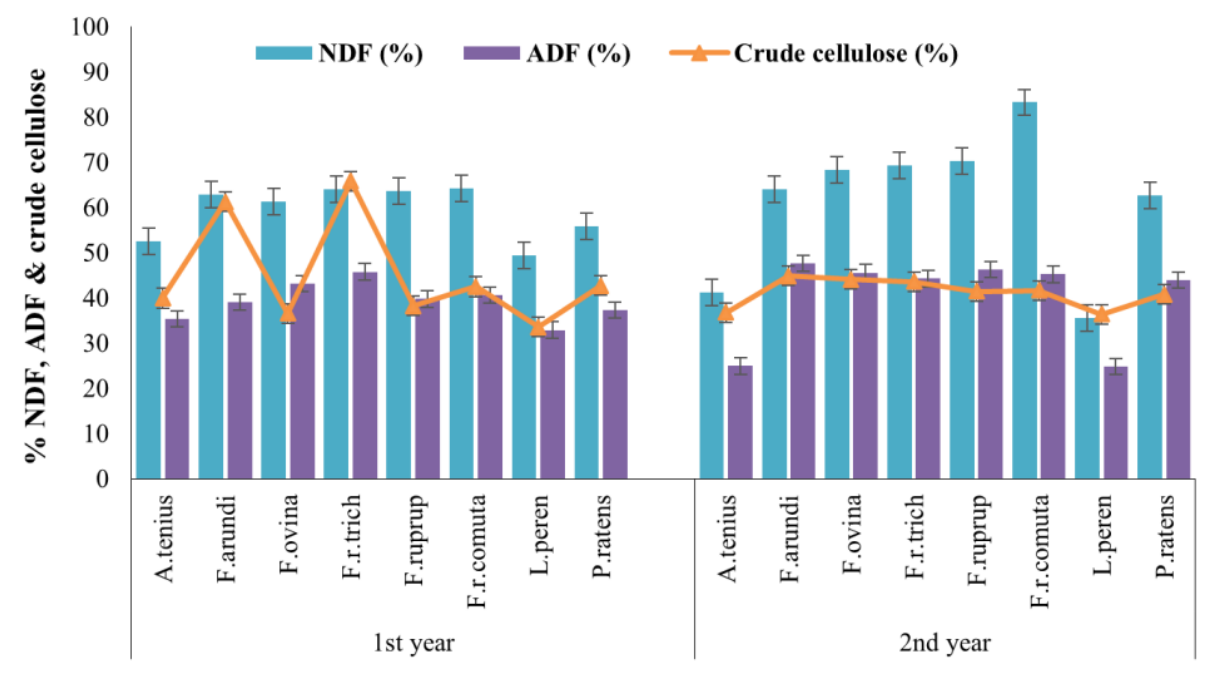

Figure 3. Acid detergent fiber (ADF), neutral detergent fiber (NDF) and crude cellulose of hay/forage as influenced by different forage species grown under Mediterranean environment

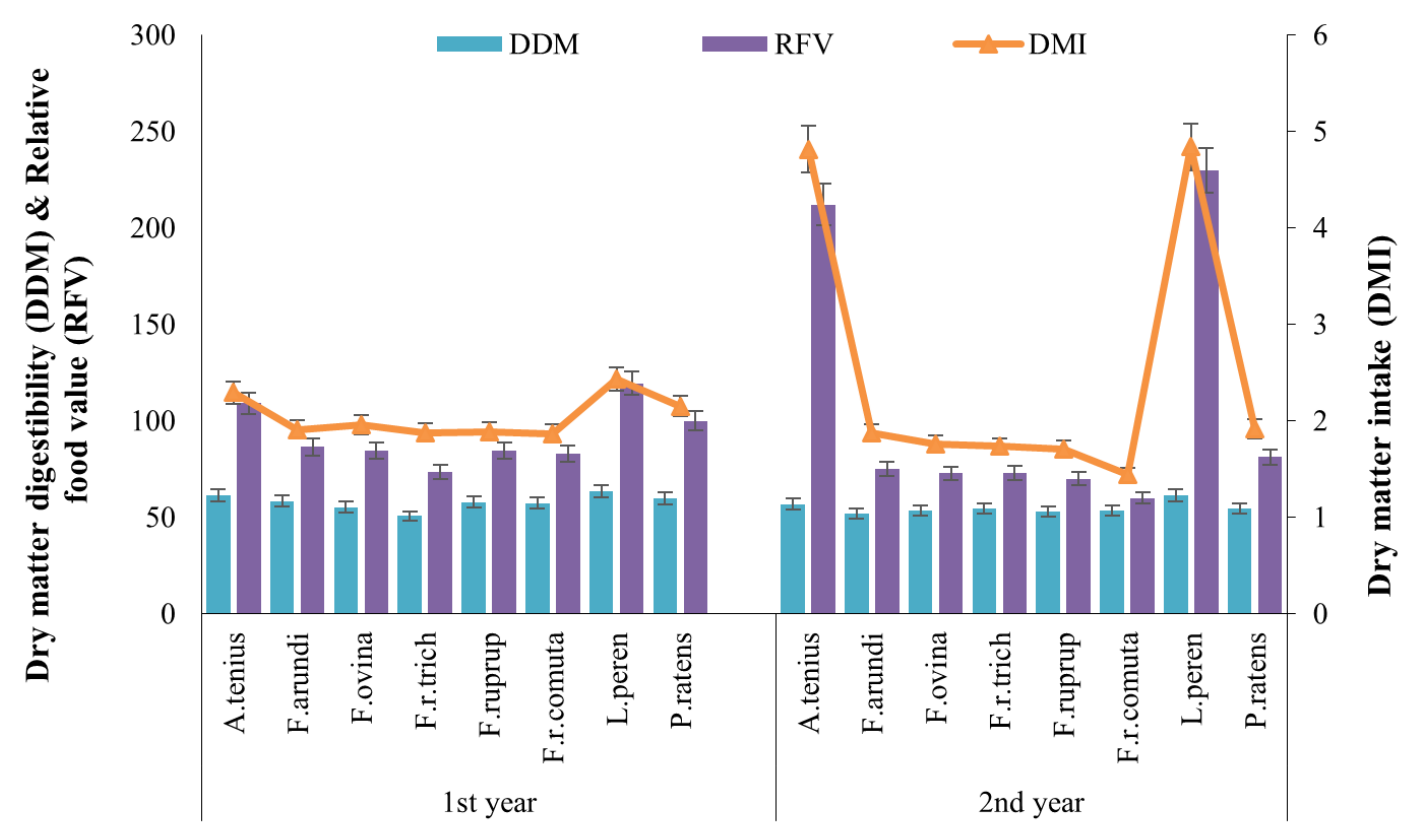

Figure 4. Intake, digestibility and relative value of dry hay/forage as influenced by different forage species grown under Mediterranean environment 


\section{Correlation coefficients among the different variables}

Correlation coefficients among the variables under study were found to be significant (Table 3). In the present study, dry yield was positively correlated with ADF and NDF, while ADF remained positively correlated with NDF. The findings are in confirmation with those of Badrzadeh (2008), who reported ADF direct relationship with NDF. On the other hand, the NDF was negatively correlated with the DDM and RFV. The ADF was negative correlated with DMI, DDM and RFV. Genotypic differences in terms of all quality parameters were found significant, while ADF ratio was non-significant, our results are in accordance with the findings of (Y1lmaz and Erol, 2015). Bani et al. (2007) recorded an inverse relationship between forage fiber fractions and DM digestibility.

Table 3. Correlation coefficients between different studied parameters

\begin{tabular}{|c|c|c|c|c|c|c|c|c|c|c|c|c|c|c|}
\hline $\begin{array}{c}\text { Study } \\
\text { parameters }\end{array}$ & $\begin{array}{c}\text { Dry } \\
\text { yield } \\
\left(\mathbf{t ~ h a}^{-1}\right)\end{array}$ & $\begin{array}{c}\text { Crude } \\
\text { ash } \\
(\%)\end{array}$ & $\begin{array}{c}\text { Crude } \\
\text { protein } \\
(\%)\end{array}$ & $\begin{array}{l}\text { Crude } \\
\text { oil }(\%)\end{array}$ & $\begin{array}{c}\text { Crude } \\
\text { cellulose } \\
(\%)\end{array}$ & $\begin{array}{c}\text { NDF } \\
(\%)\end{array}$ & $\begin{array}{l}\text { ADF } \\
(\%)\end{array}$ & $\begin{array}{c}\text { Crude } \\
\text { ash yield } \\
\left(\mathbf{t ~ h a}^{-1}\right)\end{array}$ & $\begin{array}{c}\text { Protein } \\
\text { yield } \\
\left(\mathbf{t ~ h a}^{-1}\right)\end{array}$ & $\begin{array}{c}\text { Crude } \\
\text { oil } \\
\left(\mathbf{t ~ h a}^{-1}\right)\end{array}$ & $\begin{array}{c}\text { NDF } \\
\left(\mathbf{t ~ h a}^{-1}\right)\end{array}$ & $\begin{array}{c}\text { ADF } \\
\left(t \text { ha }^{-1}\right)\end{array}$ & $\begin{array}{c}\text { Dry } \\
\text { matter } \\
\text { intake }\end{array}$ & $\begin{array}{c}\begin{array}{c}\text { Digestible } \\
\text { dry } \\
\text { matter }\end{array} \\
\end{array}$ \\
\hline & \multicolumn{14}{|c|}{ 1st year } \\
\hline Crude ash, $\%$ & 0.608 & & & & & & & & & & & & & \\
\hline Crude protein, $\%$ & -0.328 & 0.427 & & & & & & & & & & & & \\
\hline Crude oil, \% & -0.273 & -0.169 & 0.513 & & & & & & & & & & & \\
\hline $\begin{array}{c}\text { Crude cellulose, } \\
\%\end{array}$ & 0.407 & 0.406 & -0.268 & -0.544 & & & & & & & & & & \\
\hline NDF, $\%$ & 0.354 & -0.032 & $-0.762 *$ & $-0.917 * *$ & 0.520 & & & & & & & & & \\
\hline $\mathrm{ADF}, \%$ & 0.317 & -0.169 & $-0.751 *$ & $-0.724 *$ & 0.555 & $0.847 * *$ & & & & & & & & \\
\hline $\begin{array}{c}\text { Crude ash yield, } \\
\text { t/ha }\end{array}$ & $0.913 * *$ & $0.840 * *$ & -0.047 & -0.220 & 0.519 & 0.207 & 0.091 & & & & & & & \\
\hline $\begin{array}{c}\text { Protein yield, } \\
\text { t/ha }\end{array}$ & $0.959 * *$ & $0.744 *$ & -0.075 & -0.089 & 0.308 & 0.115 & 0.055 & $0.954 * *$ & & & & & & \\
\hline $\begin{array}{l}\text { Crude oil, } \\
\text { yield/ha }\end{array}$ & 0.636 & 0.352 & 0.117 & 0.543 & -0.208 & -0.431 & -0.336 & 0.565 & $0.748^{*}$ & & & & & \\
\hline $\mathrm{NDF}, \mathrm{t} / \mathrm{ha}$ & $0.973 * *$ & 0.562 & -0.443 & -0.463 & 0.524 & 0.550 & 0.487 & $0.877 * *$ & $0.884 * *$ & 0.451 & & & & \\
\hline $\mathrm{ADF}, \mathrm{t} / \mathrm{ha}$ & $0.965^{* *}$ & 0.515 & -0.465 & -0.438 & 0.535 & 0.534 & 0.550 & $0.840^{* *}$ & $0.863^{* *}$ & 0.462 & $0.989 * *$ & & & \\
\hline Dry matter intake & -0.318 & 0.061 & $0.760^{*}$ & $0.906 * *$ & -0.522 & $-0.998 * *$ & $-0.851 * *$ & -0.175 & -0.077 & 0.460 & -0.520 & -0.504 & & \\
\hline $\begin{array}{l}\text { Digestible dry } \\
\text { matter }\end{array}$ & -0.332 & 0.093 & 0.688 & 0.699 & -0.629 & $-0.783 *$ & $-0.983 * *$ & -0.138 & -0.088 & 0.313 & -0.487 & -0.562 & $0.783^{*}$ & \\
\hline \multirow[t]{2}{*}{$\begin{array}{c}\text { Relative feed } \\
\text { value }\end{array}$} & -0.328 & 0.084 & $0.773^{*}$ & $0.875^{* *}$ & -0.589 & $-0.972 * *$ & $-0.945 * *$ & -0.161 & -0.073 & 0.440 & -0.525 & -0.542 & $0.974 * *$ & $0.903 * *$ \\
\hline & \multicolumn{14}{|c|}{ 2nd year } \\
\hline Crude ash, $\%$ & 0.210 & & & & & & & & & & & & & \\
\hline Crude protein, $\%$ & 0.100 & $0.720 *$ & & & & & & & & & & & & \\
\hline Crude oil, \% & -0.411 & 0.357 & 0.386 & & & & & & & & & & & \\
\hline $\begin{array}{c}\text { Crude cellulose } \\
\%\end{array}$ & 0.334 & -0.146 & -0.705 & -0.459 & & & & & & & & & & \\
\hline NDF, \% & 0.016 & -0.523 & $-0.747 *$ & -0.693 & $0.779 *$ & & & & & & & & & \\
\hline ADF, $\%$ & 0.174 & -0.240 & $-0.717 *$ & -0.624 & $0.919 * *$ & $0.905 * *$ & & & & & & & & \\
\hline $\begin{array}{c}\text { Crude ash yield, } \\
\text { t/ha }\end{array}$ & $0.906 * *$ & 0.601 & 0.396 & -0.192 & 0.201 & -0.218 & 0.029 & & & & & & & \\
\hline $\begin{array}{c}\text { Protein yield, } \\
\text { t/ha }\end{array}$ & $0.864 * *$ & 0.541 & 0.585 & -0.146 & -0.074 & -0.355 & -0.209 & $0.939 * *$ & & & & & & \\
\hline $\begin{array}{l}\text { Crude oil, } \\
\text { yield/ha }\end{array}$ & $0.867 * *$ & 0.378 & 0.327 & 0.081 & 0.068 & -0.373 & -0.186 & $0.862 * *$ & $0.871 * *$ & & & & & \\
\hline NDF, t/ha & $0.808 *$ & -0.161 & -0.375 & $-0.728 *$ & $0.720^{*}$ & 0.587 & 0.654 & 0.592 & 0.468 & 0.466 & & & & \\
\hline $\mathrm{ADF}, \mathrm{t} / \mathrm{ha}$ & $0.872 * *$ & 0.043 & -0.283 & -0.617 & $0.716^{*}$ & 0.441 & 0.610 & $0.732 *$ & 0.566 & 0.583 & $0.967^{* *}$ & & & \\
\hline Dry matter intake & -0.070 & 0.321 & $0.737 *$ & 0.610 & $-0.883 * *$ & $-0.950 * *$ & $-0.987 *$ & 0.093 & 0.302 & 0.283 & -0.590 & -0.514 & & \\
\hline $\begin{array}{l}\text { Digestible dry } \\
\text { matter }\end{array}$ & -0.154 & 0.298 & $0.748^{*}$ & 0.613 & $-0.862 * *$ & $-0.822 *$ & $-0.898 * *$ & -0.008 & 0.259 & 0.236 & -0.645 & -0.610 & $0.863 * *$ & \\
\hline $\begin{array}{l}\text { Relative feed } \\
\text { value }\end{array}$ & -0.060 & 0.327 & $0.753^{*}$ & 0.607 & $-0.890 * *$ & $-0.949 * *$ & $-0.989 * *$ & 0.101 & 0.320 & 0.299 & -0.590 & -0.517 & $0.998 * *$ & $0.893 * *$ \\
\hline
\end{tabular}




\section{Conclusion}

The results from this study revealed that significant variability exists among forage species under study in terms of their potential for herbage yield and nutritive value under Mediterranean environment. This indicates that there is a considerable potential for selecting appropriate forage species, which have the adequate nutritional quality to improve forage supply for as well as to meeting ruminant dietary requirements. It is clear that the potentiality of Festuca species as forage and pasture plants under prevalent agro-climatic conditions is very high due to specific nutritional characteristics. $F$. arundinacea can also be promoted as forage and pasture specie due to higher potential to yield dry matter while using $F$. rubra as a pasture plants to improve natural grassland seems to be more suitable.

\section{REFERENCES}

[1] AOAC (Association of Official Analytical Chemists) (2000): Official Methods of Analysis. - AOAC, Arlington, VA.

[2] Akdeniz, H., Koc, A., Islam, M. S., EL Sabagh, A. (2018a): Performances of hairy vetch varieties under different locations of Mediterranean environment. - Fresenius Environmental Bulletin 27(6): 4263-4269.

[3] Akdeniz, H., Koc, A., Hossain, A., El Sabagh, A. (2018b): Nutritional values of four hairy vetch (Vicia villosa Roth) varieties grown under Mediterranean environment. Fresenius Environmental Bulletin 27(8): 5385-5390.

[4] Badrzadeh, M., Zaragarzadeh, F., Esmaielpour, B. (2008): Chemical composition of some forageVicia spp. in Iran. - J. Food, Agric. Env. 6(2): 178-180.

[5] Bani, P, Minuti, A, Obonyo, L, Ligabue, M, Ruozzi, F. (2007): Genetic and environmental influences on in vitro digestibility of alfalfa. - Italian Journal of Animal Science 6: 251-253.

[6] Barutcular, C., Dizlek, H., EL Sabagh, A., Sahin, T., M., Islam, M. S. (2016a): Nutritional quality of maize in response to drought stress during grain-filling stages in mediterranean climate condition. - J. Exp. Biol. Agric. Sci. 4: 644-652.

[7] Barutcular, C., EL Sabagh, A., Konuskan, O., Saneoka, H. (2016b): Evaluation of maize hybrids to terminal drought stress tolerance by defining drought indices. - J. Exp. Biol. Agric. Sci. 4: 610-616.

[8] Barutcular, C., Yıldırım, M., Koc, M., Akıncı, C., Tanrıkulu, A., El Sabagh, A., Saneoka, H., Ueda, A., Islam, M. S., Toptas, I., Albayrak, O. (2016c): Quality traits performance of bread wheat genotypes under drought and heat stress conditions. - Fresen Environ Bull 25(12a): 6159-6165.

[9] Barutcular, C., EL Sabagh, A, Koç, M., Ratnasekera, D. (2017): Relationships between grain yield and physiological traits of durum wheat varieties under drought and high temperature stress in Mediterranean conditions. - Fresen Environ Bull 26(4): 4282-4291.

[10] Bean, B., Becker, J., Robinson, J., Pietsch, D. (2011): Limited Irrigated Texas Panhandle Sorghum Hay Trial. - Agri Life Extension Texas A\&M System, Amarillo, TX.

[11] Beard, J. B. (2002): Turf Management for Golf Courses. - Ann Arbor Press, Chelsea, Michigan.

[12] Below, F. E. (1995): Nitrogen Metabolism and Crop Productivity. - In: Pessarakli, M. (ed.) Handbook of Plant and Crop Physiology. Marcel Dekker Inc., New York, pp. 275301.

[13] Carvalho, G. G. P., Garcia, R., Pires, A. J. V., Pereira, O. G., Fernandes, F. E. P., Obeid, J. A., Carvalho, B. M. A. (2007): Fracionamento de carboidratos de silagem de capim- 
elefante emurchecido ou com farelo de cacau. - Revista Brasileira de Zootecnia 36: 10001005 .

[14] Erdogan, H.E. (2013): Soil Definition Guide. ISBN: 978-605-4672-20-2.

[15] Hamed, A. H. M., Abbas, S. O., Ali, K. A., Elimam, M. E. (2015): Stover yield and chemical composition in some sorghum varieties in Gadarif state, Sudan. - Animal Review 2: 68-75. DOI: 10.18488/journal.ar/2015.2.3/101.3.68.75.

[16] Iqbal, M. A., Abdul, H., Imtiaz, H., Muzammil, H. S., Tanveer, A., Abdul, K., Zahoor, A. (2019): Competitive indices in cereal and legume mixtures in a South Asian environment. - Agronomy Journal 111: 242-249.

[17] Iqbal, M. A., Asif, I., Rana, N. A. (2018): Spatio-temporal reconciliation to lessen losses in yield and quality of forage soybean (Glycine max L.) in soybean-sorghum intercropping systems. - Bragantia 77: 283-291.

[18] Iqbal, M. A., Brandon, J. B., Asif, I., Rana, N. A., Zubair, A., Haroon, Z. K., Bilal, A. (2017): Agro-botanical response of forage sorghum-soybean intercropping systems under atypical spatio-temporal patterns. - Pakistan Journal of Botany 49: 987-994.

[19] Jiang, Y., Huang, B. (2001): Physiological responses to heat stress alone or in combination with drought: A comparison between tall fescue and perennial ryegrass. HortScience 36: 682-686.

[20] Kanapeckas, J., Lemeziene N., Stukonis V., Tarakanovas P. (2008): Drought tolerance of turfgrass genetic resources. - Biologja 54: 121-124.

[21] Kering, M. K., Butler, T. J., Biermacher, J. T., Guretzky, J. A. (2012): Biomass yield and nutrient removal rates of perennial grasses under nitrogen fertilization. - BioEnergy Research 5(1): 61-70.

[22] Kumar, R., Singh, M., Tomar, S. K., Meena, B. S., Rathore, D. K. (2016): Productivity and nutritive parameters of fodder maize under varying plant density and fertility levels for improved animal productivity. - Indian J. Animal Resch 50: 199-202.

[23] Lemus, R., Brummer, E. C., Burras, C. L., Moore, K. J., Barker, M. F., Molstad, N. E. (2008): Effects of nitrogen fertilization on biomass yield and quality in large fields of established switchgrass in southern Iowa, USA. - Biomass and Bioenergy 32(12): 11871194.

[24] Minson, D. J. (1990): Forage in Ruminant Nutrition. - Academic Press, New York. DOI: 10.1016/B978-0-12-498310-6.50025-0.

[25] Muir, J. P., Sanderson, M. A., Ocumpaugh, W. R., Jones, R. M., Reed, R. L. (2001): Biomass production of 'Alamo'switchgrass in response to nitrogen, phosphorus, and row spacing. - Agronomy Journal 93(4): 896-901.

[26] Özpinar, H., Olcayto C. Sabanci, Alptekin A. (2014): Evaluation of fescue (Festuca arundinacea Schreb. and Festuca rubra L.) populations grown under Aegean region conditions. - ANADOLU, J. of AARI 24(2): 32-40.

[27] Poetsch, E. M., Resch, R., Krautzer, B. (2016): Variability of yield and forage quality between three heading groups of english ryegrass (Lolium perenne L.) during the first growth / Variabilität von Ertrag und Futterqualität zwischen drei Reifegruppen von Englischem Raygras (Lolium perenne L.) im Verlauf des ersten Aufwuchses. - Die Bodenkultur: Journal of Land Management, Food and Environment 67(2): 69-75.

[28] Prendes, J. A. O., Palencia, P. (2015): Morphological characterization and turf performance of Paula hard fescue and Casero colonial bentgrass selections under low maintenance conditions. - Czech J. Genet. Plant Breed. 51(3): 117-22.

[29] Ribeiro, K. G., Pereira, O. G., Valadares Filho, S. C., Garcia, R., Cabral, L. S. (2001): Caracterização das frações que constituem as proteínas e os carboidratos e respectivas taxas de digestão, do feno de capim-tifton 85 de diferentes idades de rebrota. - Revista Brasileira de Zootecnia 30: 589-595.

[30] Roche, J. R., Blache, D., Kay, J. K., Miller, D. R., Sheahan, A. J., Miller, D. W. (2008): Neuroendocrine and physiological regulation of intake with particular reference to domesticated ruminant animals. - Nutrition Research Reviews 21: 207-234. 
[31] Senthil-Kumar, M., Kumar, G., Srikanthbabu, V., Udayakumar, M. (2007): Assessment of variability in acquired thermotolerance: potential option to study genotypic response and the relevance of stress genes. - Journal of Plant Physiology 164(2): 111-125.

[32] Smit, H. J., Tas, B. M., Taweel, H. Z., Tamminga, S., Elgersma, A. (2005a): Effects of perennial ryegrass (Lolium perenne L.) cultivars on herbage production, nutritional quality and herbage intake of grazing dairy cows. - Grass and Forage Science 60(3): 297309.

[33] Smit, H. J., Tas, B. M., Taweel, H. Z., Tamminga, S., Elgersma, A. (2005b): Sward characteristics important for intake in six Lolium perenne varieties. - Grass and Forage Science 60: 128-135.

[34] Snedecor, G. W., Cochran, W. G. (1994): Statistical Methods. $8^{\text {th }}$ Ed. - Oxford and IBH Publishing Company, Calcutta, India.

[35] Stanisavljević, R. S., Vučković S. M., Simić A. S., Marković J. P., Lakić Z. P., Terzić D. V., Đokić D. J. (2012): Acid and temperature treatments result in increased germination of seeds of three fescue species. - Not. Bot. Hortic. Agrobot. 40: 220-226.

[36] Tilley, J. M. A., Terry, R. A. (1963): A two-stage technique for the in vitro digestion of forage crops. - Journal of British Grassland Society 18: 104-111. DOI: 10.1111/j.13652494.1963.

[37] Turgeon, A. J. (1980): Turfgrass Management. - Reston Pub., Reston, VA.

[38] Undersander, D., Mertens, D. W., Theix, N. (1993): Forage Analysis Procedures. National Forage Testing Association, Omaha, NE.

[39] Van Soest, P. J., Robertson, J. B., Lewis, B. A. (1991): Method for dietary fibre, neutral detergent fibre and non-starch polysaccharides in relation to animal nutrition. - Journal of Dairy Science 74: 3588-3597.

[40] van Vuuren, A. M., van der Koelen, C. J., Valk, H., de Visser, H. (1993): Effects of partial replacement of ryegrass by low-protein feeds on rumen fermentation and nitrogen loss by dairy cows. - Journal of Dairy Science 76: 2982-2993.

[41] van Wijk, A. J. P., Boonman, J. G., Rumball, W. (1993): Achievements and perspectives in the breeding of forage grasses and legumes. - In: Baker, M. J. (ed.) XVIIth International Grassland Congress, Wellington, New Zealand, pp. 379-384.

[42] Wang, K., Zhang, X., Ervin, E. (2012): Antioxidative responses in roots and shoots of creeping bentgrass under high temperature: effects of nitrogen and cytokinin. - Journal of Plant Physiology 169(5): 492-500.

[43] Wims, C. M., Mcevoy, M., Delaby, L., Boland, T. M., O'Donovan, M. (2013): Effect of perennial ryegrass (Lolium perenne L.) cultivars on the milk yield of grazing dairy cows. - Animal 7(3): 410-421.

[44] Xu, S., Li, J., Zhang, X., Wei, H., Cui, L. (2006): Effects of heat acclimation pretreatment on changes of membrane lipid peroxidation, antioxidant metabolites, and ultrastructure of chloroplasts in two cool-season turfgrass species under heat stress. - Environmental and Experimental Botany 56(3): 274-285.

[45] Y1lmaz, M. F., Erol, A. (2015): Determination of forage yields and quality characteristics of some common vetch (Vicia sativa L.) genotypes. - Türk Tarım ve Doğa Bilimleri Dergisi 2(2): 142-151.

[46] Yıldırım, M., Barutcular, C., Hossain, A., Koç, M., Dizlek, H., Akinci, C., Toptaş, I., Basdemir, F., Islam, M.S., EL Sabagh, A. (2018): Assessment of the grain quality of wheat genotypes grown under multiple environments using GGE Biplot analysis. Fresen Environ Bull 27(7): 4830-4837. 